\title{
CHANGES IN THE MORPHOLOGY OF THE ROOT SYSTEM OF WHEAT INOCULATED WITH Azospirillum brasilense Sp7 AND BACTERIOPHAGE FAb-Sp7
}

\section{O.I. GULII', 2, 3, M.K. SOKOLOVA', O.I. SOKOLOV1, O.V. IGNATOV1}

1Institute of Biochemistry and Physiology of Plants and Microorganisms, Russian Academy of Sciences, 13 , Prospekt Entuziastov, Saratov, 410049 Russia, e-mail guliy_olga@mail.ru;

${ }^{2}$ N.I. Vavilov Saratov State Agrarian University, 1, Teatralnaya Ploshchad', Saratov, 410012 Russia;

${ }^{3}$ Saratov Veterinary Research Institute, Russian Academy of Sciences, 6, Ulitsa 53-i Strelkovoi Divizii, Saratov, 410028 Russia

Received March 30, 2015

\section{Abstract}

The Azospirillum is one of the most common objects to study associative interactions between bacteria and plants. In the rhizosphere of cereals the Azospirillum cells form effective association and demonstrate a stimulating effect on plant growth and development, in particular in wheat. However, the details of these positive effects are still unknown. For example, there is no evidence of whether the Azospirillum cells are infected with bacteriophages, and little is known about the role that the bacteriohages of soil microorganisms can play in the development of associative relationship between microorganisms and plants. Nevertheless, the bacteriophages are well known to control the bacteria number in the population and be involved in genetic transduction. Note that the studied bacteriophages are mostly isolated from environment, in particular, from soil, while the bacteriphages of associative soil bacteria still remain poorly studied. To evaluated changes in the morphology of the wheat (Triticum aestivum L.) root system in Saratovskaya 29 variety after inoculation with Azospirillum brasilense $\mathrm{Sp} 7$ bacterial cells and bacteriophage $\mathrm{FAb}-\mathrm{Sp} 7$, isolated from these cells, we first inoculated the 3-day old wheat seedlings with $A$. brasilense $\mathrm{Sp} 7$ at $10^{8}, 10^{6}$, $10^{4}$ cells per $1 \mathrm{ml}$. It resulted in a decrease in the length of the root, and the number of lateral roots grew considerably at $10^{2}$ cells per $1 \mathrm{ml}$. After treatment wiht bacteriophage $\mathrm{FAb}-\mathrm{Sp} 7$ an average number of roots remained unchanged. It was shown that wheat seedling inoculation with Azospirillum suspension resulted in a 3-fold decrease in root elongation zone, and the suction zone reduced 1.5 times. Treatment of wheat seedlings with a suspension containing Azospirillum and phages resulted in a 3.3-fold decrease in the tensile zone, but the root hair zone remained unchanged. Using confocal microscopy we demonstrated that incubation of wheat seedlings with Azospirillum at $10^{2}$ cells per $1 \mathrm{ml}$ significantly increased the number and length of root hairs (on average by $40 \%$ ) compared with the control. It was shown that a simultaneous inoculation with Azospirillum $\mathrm{Sp} 7$ cells and bacteriophage FAb-Sp7 also increased the number and length of root hairs (60\% on average) compared with control. It is suggested that bacteriophages of Azospirillum are involved into complex interaction of bacteria with wheat root system, and can influence on and, ultimately, determine the effectiveness of associative relationships between the plant and microorganisms.

Keywords: Azospirillum brasilense, bacteriophages, wheat, root system.

The representatives of Azospirillum are among the most common objects for the study of associative interactions between bacteria and plants [1]. Azospirillae belong to $\alpha$-proteobacteria of the Rhodospirillaceae family capable of assimilating atmospheric nitrogen. In natural conditions, they can colonize both the surface and internal tissues of plant roots, mainly in cereals [2-4], and formation of these symbioses increases cereal productivity [5-8]. As to $A$. brasilense $\mathrm{Sp} 7$, in the $1990 \mathrm{~s}$, the presence of strain cells on the root surface only was demonstrated in a series of studies [3-4, 9].

A multifactorial positive effect of the Azospirillum bacteria on plant growth, development and productivity is known. In this regard, high nitrogenfixing activity, production of indole-3-acetic acid and other plant hormones, 
fungicidal and bactericidal activity and the ability to synthesize physiologically active substances of high molecular weight are considered significant features [7].

Bacteriophages of soil microorganisms attract the attention of researchers due to their prevalence, diversity and important ecological role [10, 11]. In most cases, bacteriophages were isolated from various environmental objects, including soil [12-17], and just some studies describe bacteriophages from soil bacteria associations. Thus, in the study of 24 soil bacteriophage strains that stimulate the growth of plants, it was first found [18] that most bacteria isolates belong to the family of Azospirillum. Bacteriophages were isolated from 11 of 24 strains analyzed, including $A$. brasilense Cd, $A$. brasilense Sp7, A. brasilense Sp245, A. brasilense $\mathrm{Wb} 1$, A. lipoferum $\mathrm{B}-518, A$. dobereinerae and a number of other strains. The role of bacteriophages in associative interactions of Azospirillum cells with plants is of particular importance.

Our purpose was to study the effect of Azospirillum bacteriophages on the growth and development of the root system in wheat seedlings in an in vitro microorganism-plant system.

Technique. Spring wheat seedlings (var. Saratovskaya 29), Azospirillum brasilense strain $\mathrm{Sp} 7$ (collection of the Institute of Biochemistry and Physiology of Plants and Microorganisms of the Russian Academy of Science) and bacteriophage $\mathrm{FAb}-\mathrm{Sp} 7$ isolated by us from the same strain were used as the model for the study of associative interaction. A. brasilense $\mathrm{Sp} 7$ was grown on LB solid medium, then in liquid LB medium [19] and cultured in Erlenmeyer flasks $(250 \mathrm{ml})$ at a rotary shaker with aeration $(160 \mathrm{rev} / \mathrm{min})$ at $30 \pm 1{ }^{\circ} \mathrm{C}$ for $18-20$ hours.

Bacteriophage preparations were obtained as described [19]. The microorganism culture was cooled at $+4{ }^{\circ} \mathrm{C}$ for $1.5-2.0$ hours for the stimulation of the release of bacteriophages from the cells, after which the cells were separated by centrifugation at $2,500 \mathrm{~g}$ for $40 \mathrm{~min}$, and $1 / 5$ of the volume of $20 \%$ polyethylene glycol solution (PEG-6000 Panreac, Spain) with 1.6 M NaCl (PEG$\mathrm{NaCl}$ ) was added to the supernatant, covered with ice and placed in a refrigerator for 2.0 hours to flocculate the particles. Samples were centrifuged at 12,000 g for $30 \mathrm{~min}$, the supernatant was removed. Then, $1 \mathrm{ml}$ of TE buffer $(10 \mathrm{mM}$ Tris-HCl, $1 \mathrm{mM}$ EDTA, pH 7.5-8.0) was added to the pellet, mixed thoroughly and centrifuged for $5 \mathrm{~min}$ at $10,000 \mathrm{~g}$. The supernatant was collected in a sterile container, $1 / 5$ of the volume of $\mathrm{PEG}-\mathrm{NaCl}$ was added, the pellet was quickly vortexed and centrifuged for 5 minutes at $6,500 \mathrm{~g}$. The resulting pellet was resuspended in $1 \mathrm{ml}$ of TE buffer and stored at $-16^{\circ} \mathrm{C}$.

The microbial cell titer was determined by the $\mathrm{OD}_{540}$ using the Specol221 instrument (DDR) in a cuvette with the optical path length of $1.0 \mathrm{~cm}$ and recalculated for the dry cell weight $(\mathrm{g} / \mathrm{l})$ using calibration curves. The phage particle titer was determined spectrophotometrically using a Specord BS-250 instrument (Analytik Jena, Germany) in a $1 \mathrm{~mm}$ cuvette. We proceeded from the fact that 30 optic units match the density of phage suspension of $2 \times 10^{14}$ particles/ml [20]. The following formula was used for the phage titer computation: $\left(\mathrm{A}_{269}-\mathrm{A}_{320}\right) \times 5 \times 10^{14} / 15$.

Triticum aestivum L. wheat seeds (Saratovskaya 29) were washed with distilled water with $1 \%$ household detergent solution, treated with $6 \%$ calcium hypochlorite for $10 \mathrm{~min}$ and washed with sterile distilled water three times. To accelerate germination, seeds were soaked in warm $\left(45^{\circ} \mathrm{C}\right)$ sterile distilled water for 1 hour, after which 10 to 12 seeds were put in sterile Petri dishes with capron substrate, $10 \mathrm{ml}$ of sterile distilled water was added and the seeds were placed in a thermostat at $24^{\circ} \mathrm{C}$ for 3 days.

To assess the impact of $A$. brasilense $\mathrm{Sp} 7$ on seedlings, bacteria were 
washed out of the medium with sterile distilled water, using thrice centrifugation at $3,000 \mathrm{~g}$ for $5 \mathrm{~min}$. Sterile $A$. brasilense $\mathrm{Sp} 7$ suspension $(20 \mathrm{ml})$ of $10^{8}, 10^{6}$, $10^{4}$, and $10^{2}$ cells $/ \mathrm{ml}$ (without bacteriophages) was added to 3 -day-old seedlings, then the seedlings were grown for 4 days at $23{ }^{\circ} \mathrm{C}$ (thrice repetitions for each variant). The results were registered at the day 7 . Untreated seedlings obtained in sterile distilled water under similar conditions were the control.

To study the effects of bacteriophages on the growth, various dilutions of the FAb-Sp7 preparation isolated from $A$. brasilense Sp7 cells was used. At the same time, 3-day-old wheat seedlings were placed into sterile glass tubes and their roots were treated with the bacteriophage suspension in sterile water for 3 hours. Next, the seedlings were put in sterile Petri dishes containing sterile water and allowed to stay in a thermostat at $23{ }^{\circ} \mathrm{C}$. The results were registered at the day 7. Seedlings not treated with bacteriophage grown in sterile distilled water under similar conditions were the control.

Root hairs at $1 \mathrm{~mm}$ of the root length were calculated using a confocal TCS SP5 microscope (Leica Microsystems GmbH, Germany). A total of 10 roots were stained for 5 minutes in methylene blue aqueous solution by a conventional method, then washed with water. Root zones were measured in wet preparations using a MBS-9 binocular microscope (Russia).

Statistical analysis included calculation of arithmetic means and standard errors.

Results. In cereal rhizosphere, Azospirillum form highly effective micro associations demonstrating stimulating effect on plant growth and development, particularly in wheat [21]. By light and electron microscopy using fluorescent antibodies and nucleotide probes, azospirillum were found to be arranged in mucigel on root surface, and in some cases in the inner layers of parenchyma as well [21]. We could find no literature data on the impact of the infected and uninfected by bacteriophages bacteria on the associative interaction with the plant, and on the participation of the very bacteriophages in the interaction of soil microorganisms with plants. At the same time, bacteriophages play an important role as a factor regulating the number of microbial cells, and in the transfer of genetic information by transduction [22]. Therefore, we tried to identify the phenomenon of the bacteriophage impact on associative relationships between the plant and microorganisms.

1. Morphometric parameters of the root system in spring wheat (Triticum aestivum L.) var. Saratovskaya 29 seedlings inoculated with Azospirillum brasilense Sp7 (laboratory experiment)

\begin{tabular}{|c|c|c|c|c|}
\hline \multirow{2}{*}{ Variant } & \multirow{2}{*}{$\begin{array}{l}\text { Number of roots } \\
\text { per seedling, pcs }\end{array}$} & \multicolumn{2}{|c|}{ Root length, $\mathrm{cm}$} & \multirow{2}{*}{$\begin{array}{l}\text { Number of lat- } \\
\text { eral roots, pcs }\end{array}$} \\
\hline & & maximum & minimum & \\
\hline I & $5.2 \pm 0.2$ & $8.3 \pm 0.1$ & & $3.4 \pm 0.2$ \\
\hline II & $4.8 \pm 0.2$ & $4.3 \pm 0.3$ & $1.0 \pm 0.2$ & $3.0 \pm 0.2$ \\
\hline III & $4.9 \pm 0.1$ & $4.2 \pm 0.3$ & $1.0 \pm 0.1$ & $3.0 \pm 0.2$ \\
\hline IV & $4.8 \pm 0.2$ & $6.8 \pm 0.2$ & $1.9 \pm 0.2$ & $2.6 \pm 0.4$ \\
\hline V & $4.9 \pm 0.2$ & $7.6 \pm 0.2$ & $2.1 \pm 0.2$ & $4.1 \pm 0.1$ \\
\hline \multicolumn{5}{|c|}{$\begin{array}{l}\text { Not e. I - control (no inoculation); II-V }-A \text {. brasilense } \mathrm{Sp} 7 \text { suspension inoculation ( } 20 \mathrm{ml} \text {, density of } 10^{8} \\
\text { cells } / \mathrm{ml}, 10^{6} \text { cells } / \mathrm{ml}, 10^{4} \text { cells } / \mathrm{ml} \text { and } 10^{2} \text { cells } / \mathrm{ml} \text { ). Arithmetic mean values and standard deviations (errors) are } \\
\text { summarized for } 286 \text { seedlings of each variant. }\end{array}$} \\
\hline
\end{tabular}

Since most microorganisms are lysogenic, first the effect of $A$. brasilense $\mathrm{Sp} 7$ cells in the lysogenic state on the linear growth parameters of the wheat var. Saratovskaya 29 seedling root system was studied. Treatment of seedlings with Azospirillum suspensions in all studied doses was shown not to change the mean number of roots per seedling significantly (Table 1). However, the root system morphology was changed, particularly root length decreased when the seedlings were treated with suspensions of high density $\left(10^{8}, 10^{6}\right.$, and $10^{4}$ cells/ml) (Fig. 1), 
while the number of lateral roots changed significantly only with the suspension of $10^{2}$ cells $/ \mathrm{ml}$ (see Table 1). The latter may indicate the strengthening of the root system formation which is consistent with literature data on the stimulating effect of Azospirillum on wheat [23, 24].

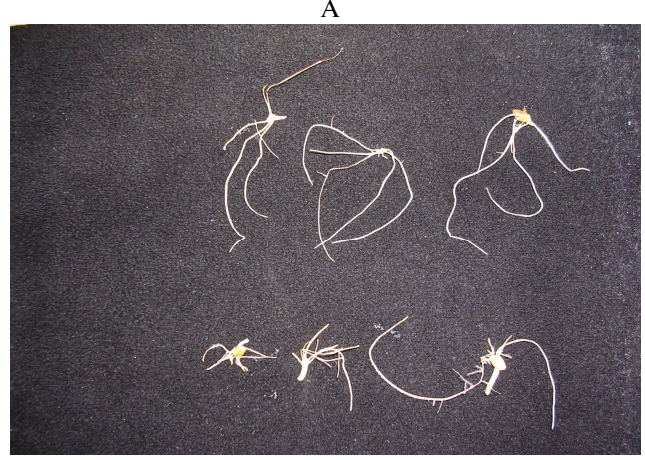

$\mathrm{C}$

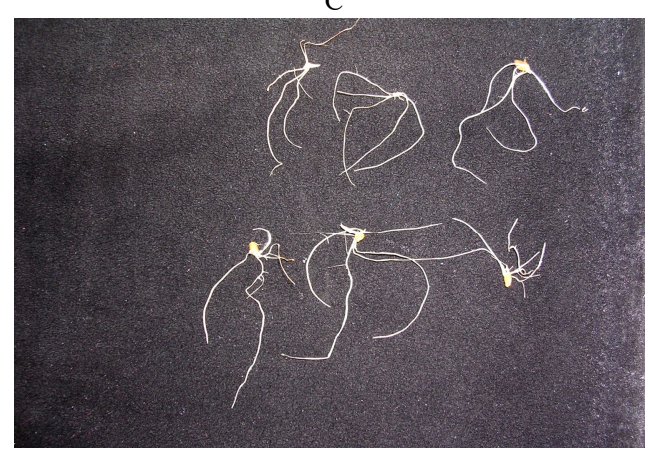

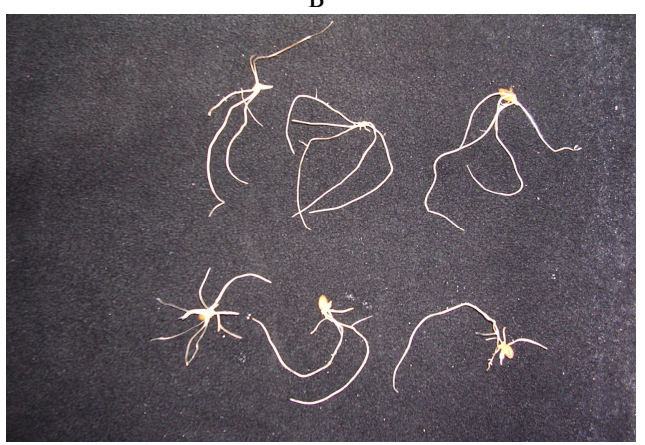

$\mathrm{D}$

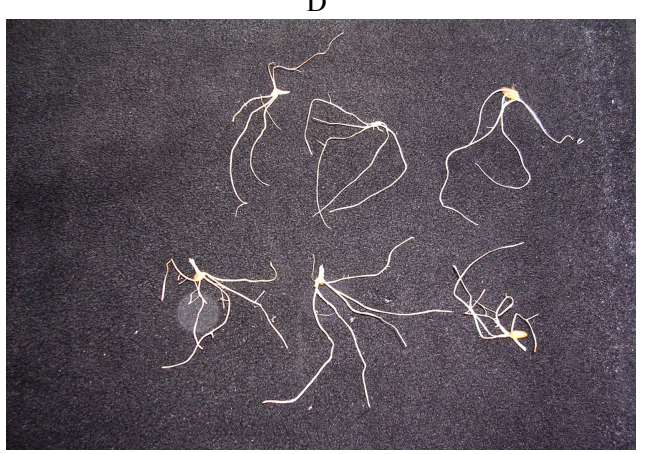

Fig. 1. Morphological changes in 7-day-old spring wheat (Triticum aestivum L.) var. Saratovskaya 29 seedling root system after Azospirillum brasilense Sp7 inoculation: A, B, C and D - suspension density under the inoculation of $10^{8}$ cells $/ \mathrm{ml}, 10^{6}$ cells $/ \mathrm{ml}, 10^{4}$ cells $/ \mathrm{ml}$ and $10^{2}$ cells $/ \mathrm{ml}$, respectively $(20 \mathrm{ml})$. In the upper ranks: control (no inoculation), in the lower ranks: inoculated samples (laboratory experiments).

2. Morphometric parameters of the root system in spring wheat (Triticum aestivum L.) var. Saratovskaya 29 seedlings inoculated with FAb-Sp7 bacteriophage isolated from Azospirillum brasilense $\mathrm{Sp} 7$ (laboratory experiments)

\begin{tabular}{l|c|c|c|c}
\hline \multirow{2}{*}{ Variant } & Number of roots & \multicolumn{2}{|c|}{ Root length, cm } & \multicolumn{2}{c}{$\begin{array}{c}\text { Number of lat- } \\
\text { eral roots, pcs }\end{array}$} \\
\cline { 3 - 4 } & per seedling, pcs & maximum & maximum & $4.0 \pm 0.2$ \\
I & $4.7 \pm 0.2$ & $8.3 \pm 0.3$ & $2.9 \pm 0.2$ & $4.2 \pm 0.2$ \\
II & $5.1 \pm 0.1$ & $6.5 \pm 0.1$ & $1.6 \pm 0.2$ & $5.5 \pm 0.2$ \\
III & $5.0 \pm 0.1$ & $7.6 \pm 0.2$ & $2.1 \pm 0.3$ &
\end{tabular}

N ot e. I - control (no inoculation); II и III - inoculation (20 $\mathrm{ml}$ of bacteriophage suspension with the titer of $10^{8}$ particles $/ \mathrm{ml}$ and $10^{6}$ particles $/ \mathrm{ml}$, respectively). Arithmetic mean values and standard deviations (errors) are summarized for 264 seedlings of each variant.

Some properties of bacteriophage FAb-Sp7 isolated from the A. brasilense $\mathrm{Sp} 7$ cells have been described earlier [18]. In our studies, the mean number of roots after the treatment of wheat seedlings with bacteriophage preparations was actually unchanged (Table 2). Under increased bacteriophage suspension density, the maximum and the minimum root length was reduced. The number of lateral roots grew only when the suspension with a density of $10^{6}$ phage particles per milliliter was used.

Simultaneous inoculation with Azospirillum suspension and phage particles resulted in a mild increase in the mean root number and in the 1.5 times decrease in the maximum root length, in the 1.8 times decrease in its minimum 
length, and in the 1.5 times increase of the number of lateral roots (Table 3).

3. Morphometric parameters of the root system in spring wheat (Triticum aestivum L.) var. Saratovskaya 29 seedlings with simultaneous inoculation with Azospirillum brasilense $\mathrm{Sp} 7$ and bacteriophage $\mathrm{FAb}-\mathrm{Sp} 7$ isolated from this strain (laboratory experiments)

\begin{tabular}{l|c|cc|c}
\hline \multirow{2}{*}{ Variant } & Number of roots & \multicolumn{2}{|c|}{ Root length, cm } & \multirow{2}{*}{$\begin{array}{c}\text { Number of lat- } \\
\text { eral roots, pcs }\end{array}$} \\
\cline { 3 - 4 } & per seedling, pcs & maximum & maximum & $4.0 \pm 0.2$ \\
I & $4.8 \pm 0.2$ & $8.3 \pm 0.3$ & $2.9 \pm 0.2$ & $4.1 \pm 0.1$ \\
II & $4.9 \pm 0.2$ & $7.6 \pm 0.2$ & $2.1 \pm 0.2$ & $6.1 \pm 0.4$ \\
III & $5.2 \pm 0.3$ & $7.9 \pm 0.4$ & $1.7 \pm 0.3$ & $5.5 \pm 0.2$ \\
IV & $5.0 \pm 0.1$ & $7.6 \pm 0.2$ & $2.1 \pm 0.3$ &
\end{tabular}

N o te. I - control (no inoculation); II - A. brasilense Sp7 inoculation ( $10^{2}$ cells $/ \mathrm{ml}, 20$ мл); III - simultaneous inoculation with $A$. brasilense Sp7 $\left(10^{2}\right.$ cells $\left./ \mathrm{ml}\right)$ and bacteriophage FAb-Sp7 $\left(10^{6}\right.$ particles $\left./ \mathrm{ml}\right)(20 \mathrm{ml})$; IV - inoculation with bacteriophage FAb-Sp7 $\left(10^{6}\right.$ particles $\left./ \mathrm{ml}, 20 \mathrm{ml}\right)$. Arithmetic mean values and standard deviations (errors) are summarized for 264 seedlings of each variant.

In case of seedling inoculation with Azospirillum, the tensile root zone decreased 3.0 times, and the absorption zone decreased 1.5 times (Table 4). When treated with Azospirillum suspension with bacteriophage added, the tensile zone decreased 3.3 times, and the zone of root hairs decreased 1.5 times.

4. Zone area and root hair development in spring wheat (Triticum aestivum L.) var. Saratovskaya 29 seedlings simultaneously inoculated with Azospirillum brasilense $\mathrm{Sp} 7$ and bacteriophage FAb-Sp7 isolated from this strain (laboratory experiments)

\begin{tabular}{|c|c|c|c|c|}
\hline \multirow{2}{*}{ Variant } & \multicolumn{2}{|c|}{ Zone area, $\mathrm{cm}^{\mathrm{a}}$} & \multirow{2}{*}{$\begin{array}{l}\text { Total root } \\
\text { length, } \mathrm{cm}\end{array}$} & \multirow{2}{*}{$\begin{array}{l}\text { Number of root hairs per } \\
1 \mathrm{~mm} \text {, pcs (versus control, \%) }\end{array}$} \\
\hline & root tensile & root hair & & \\
\hline I & $0.38 \pm 0.2$ & $9.3 \pm 0.2$ & 9.69 & $55.0(100 \%)$ \\
\hline II & $0.11 \pm 0.1$ & $6.1 \pm 0.2$ & 6.17 & $70.9(129 \%)$ \\
\hline III & $0.12 \pm 0.2$ & $6.3 \pm 0.3$ & 6.38 & $63.1(115 \%)$ \\
\hline IV & $0.18 \pm 0.1$ & $8.0 \pm 0.4$ & 8.18 & $55.6(101 \%)$ \\
\hline \multicolumn{5}{|c|}{$\begin{array}{l}\text { Not e. I - control (no inoculation); II }- \text { simultaneous inoculation with } A \text {. brasilense } \mathrm{Sp} 7\left(10^{8} \text { cells } / \mathrm{ml}\right) \text { and } \\
\left.\text { bacteriophage FAb-Sp7 (titer of } 10^{11} \text { particles } / \mathrm{ml}\right)(20 \mathrm{ml}) ; \mathrm{III}-\text { inoculation with } A \text {. brasilense } \mathrm{Sp} 7\left(10^{8} \text { cells } / \mathrm{ml} \text {, }\right. \\
20 \mathrm{ml}) \text {; IV - inoculation with bacteriophage FAb-Sp7 }\left(10^{11} \text { particles } / \mathrm{ml}, 20 \mathrm{ml}\right) ; \text { a }- \text { arithmetic mean values and } \\
\text { standard deviations (errors) are summarized for } 40 \text { roots of each variant. }\end{array}$} \\
\hline
\end{tabular}

When wheat seedlings were incubated with Azospirillum cells, an increase in the number of root hairs (15\% on average compared to control) was observed, when incubated with bacteriophage FAb-Sp7, significant changes in this value were not observed (Fig. 2, see Table 4). Simultaneous inoculation with bacteriophages FAb-Sp7 and Azospirillum strain Sp7 increased the number of root hairs significantly $(29 \%)$ while no significant changes in the formation of lateral roots were observed.

In general, after inoculation with $A$. brasilense $\mathrm{Sp} 7$ in the lysogenic state, with FAb-Sp7 bacteriophage preparation and with their combination, the total root length, the number of lateral roots, the area of root zones, the number and length of root hairs varied more or less, and significantly in case of simultaneous inoculation.

To date information indicates the positive effect of wheat plant root system inoculation with nitrogen-fixing Azospirillum bacteria but the mechanisms of this effect is not known yet. For example, there is no information about whether Azospirillum cells are infected or uninfected with bacteriophages and how the lysogenic state of bacteria affects the associative interaction with the plant. Despite the long history of using bacteriophages, they are very poorly studied in soil microorganisms, and especially it relates to their participation in the association of microorganisms with plants. Perhaps, the effect of bacteriophages is associated with their function of the control over the number and condition of the population of associative soil bacteria. Thus, they are capable of determining the inter- 
action with plant root system and, ultimately, their productivity which may be one of the ways of increasing the efficiency of microbial-plant systems.
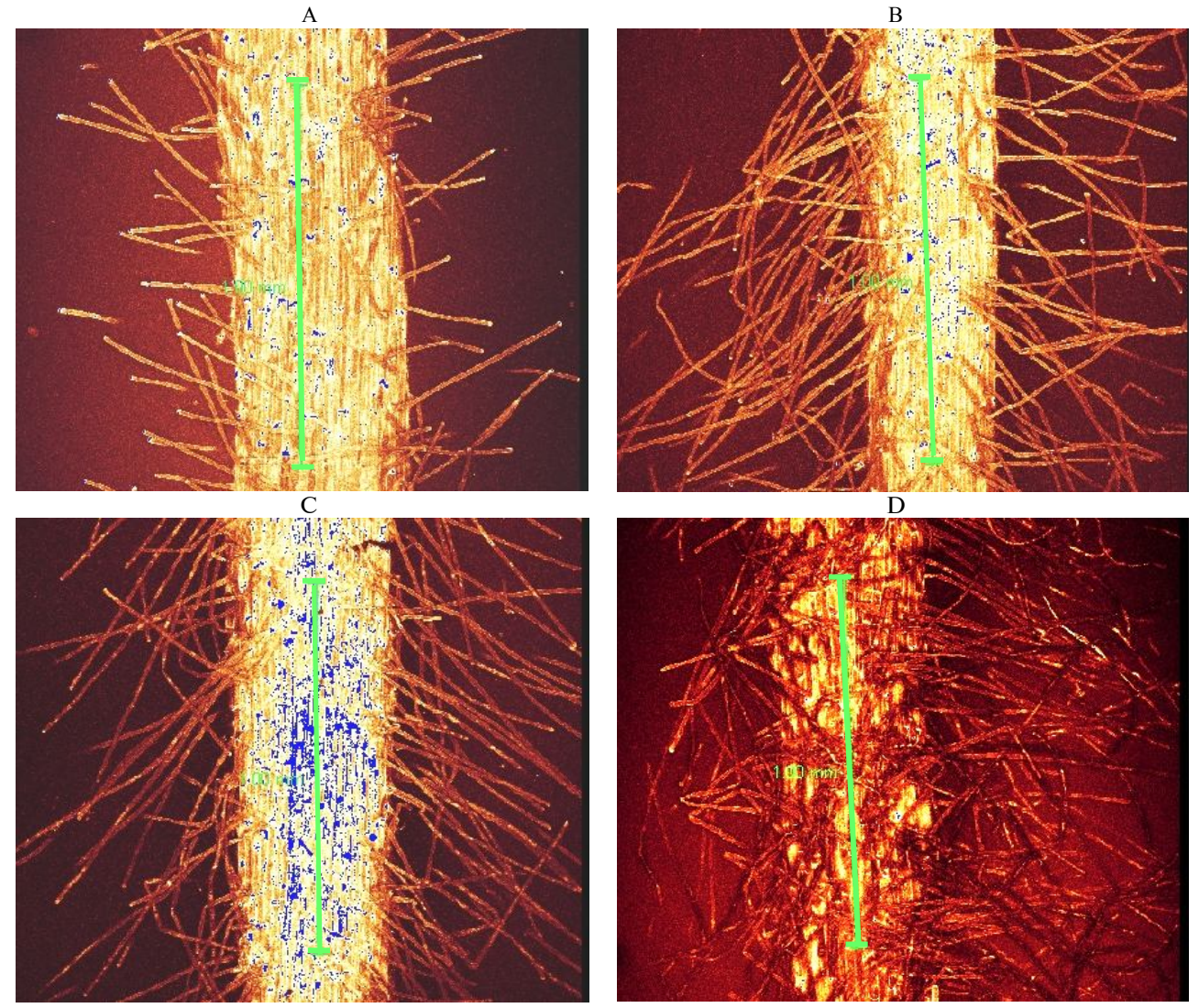

Fig. 2. Roots of 7-day-old spring wheat (Triticum aestivum L.) var. Saratovskaya 29 seedlings inoculated with Azospirillum brasilense Sp7 and bacteriophage FAb-Sp7 isolated from this strain: A control (no inoculation); B - inoculation with $A$. brasilense $\mathrm{Sp} 7$ (an increase in the number of root hairs); C - inoculation with FAb-Sp7; $\Gamma$ - inoculation with $A$. brasilense Sp7 together with FAbSp7 (a significant increase in the number of root hairs). Confocal microscopy $(\times 360$, TCS SP5, Leica Microsystems, Germany). Stained in methylene blue.

Thus, formation of symbioses with the cereal root system increases the productivity of the latter. The study of role of bacteriophages in associative interactions of Azospirillum cells with plants is of particular importance. In the example of the model strain $A$. brasilense $\mathrm{Sp} 7$ and bacteriophage FAb-Sp7 isolated from the same strain, as well as wheat seedlings, the effect of azospirillum bacteriophages on the changes in wheat root morphology was studied. Changes in the total root length, the number of lateral roots, the root zone area, the number and length of root hairs in wheat seedling root system after inoculation with $A$. brasilense $\mathrm{Sp} 7$ cells in the lysogenic state and bacteriophage $\mathrm{FAb}-\mathrm{Sp} 7$, as well as simultaneous inoculation with Azospirillum cells and bacteriophage have been shown. Significant changes in the wheat seedling root system were recorded after simultaneous inoculation with Azospirillum cells and bacteriophages. Based on the results of the study, it is suggested that bacteriophages of Azospirillum are involved into complex interaction of bacteria with wheat root system and can influence the effectiveness of associative relationships between the plant and microorganisms.

\section{R E F E R E N C E S}

1. Volkogon V.V., Mamchur A.E., Le meshko S.V., Minyailo V.G. Mikrobiolo- 
gicheskii zhurnal, 1995, 57(1): 14-19.

2. Döbereiner J., Pedrosa F.O. Nitrogen-fixing bacteria in non leguminous crop plants. Springer Verlag, Berlin, Heidelberg, NY, 1987.

3. Schloter M., Kirchhof G., Heinzmann U. Immunological studies of the wheat-rootcolonization by the Azospirillum brasilense strains Sp7 and Sp245 using strain-specific monoclonal antibodies. In: Nitrogen fixation with non-legumes. Cairo, American University of Cairo press, 1994: 291-297.

4. Assmus B., Hutzler P., Kirchhof G., Amann R., Law rence J.R., Hartmann A In situ localization of Azospirillum brasilense in the rhizosphere of wheat with fluorescently labeled, rRNA-targeted oligonucleotide probes and scanning confocal laser microscopy. Appl. Environ. Microbiol., 1995, 61(3): 1013-1019.

5. B a shan Y. Azospirillum plant growth-promoting strains are nonpathogenic on tomato, pepper, cotton, and wheat. Can. J. Microbiol., 1998, 44: 168-174 (doi: 10.1139/w97-136).

6. B ashan Y., Holguin G. Azospirillum-plant relationships: environmental and physiological advances (1990-1996). Can. J. Microbiol., 1997, 43: 103-121 (doi: 10.1139/m97-015).

7. B a shan Y., Holguin G., de-B a sh an L.E. Azospirillum-plant relationships: physiological, molecular, agricultural, and environmental advances (1997-2003). Canad. J. Microbiol., 2004, 50: 521-577 (doi: 10.1139/w04-035).

8. Thirunavukkarasu N., Mishra M.N., Spaepen S., Vanderleyden J. Gross C.A., Tripathi A.K. An extra-cytoplasmic function sigma factor and anti-sigma factor control carotenoid biosynthesis in Azospirillum brasilense. Microbiology, 2008, 154: 2096-2105 (doi: 10.1099/mic.0.2008/016428-0).

9. Hartmann A., Baldani J.I., Kirchhof G. et al. Taxonomic and ecological studies of diazotrophic rhizosphere bacteria using phylogenetic probes. In: Azospirillum VI and related microorganisms: genetics, physiology, ecology (Series G: Ecological Sciences, V. 37). SpringerVerlag, Berlin, Heidelberg, NY, 1995: 415-427.

10. Bacteriophages: Methods and protocols. Volume 1: Isolation, characterization, and interaction. A.M. Kropinski, M.R.J. Clokie (eds.). Humana Press, NY, 2009 (doi: 10.1007/978-1-60327-164-6).

11. Dwivedi B., Schmieder R., Goldsmith D.B., Edwards R.A., Breitbart M. PhiSiGns: an online tool to identify signature genes in phages and design PCR primers for examining phage diversity. BMC Bioinformatics, 2012, 13: 37 (doi: 10.1186/1471-2105-13-37).

12. Ashelford K.E., Norris S.J., Fry J.C., B ailey M.J., D ay M.J. Seasonal population dynamics and interactions of competing bacteriophages and their host in the rhizosphere. Appl. Environ. Microbiol., 2000, 66(10): 4193-4199 (doi: 10.1128/AEM.66.10.4193-4199.2000).

13. Williamson K.E., Wommack K.E., Radosevich M. Sampling natural viral communities from soil for culture-independent analyses. Appl. Environ. Microbiol., 2003, 69: 6628-6633 (doi: 10.1128/AEM.69.11.6628-6633.2003).

14. Williamson K.E., Radosevich M., Wommack K.E. Abundance and diversity of viruses in six Delaware soils. Appl. Environ. Microbiol, 2005, 71: 3119-3125 (doi: 10.1128/AEM.71.6.3119-3125.2005).

15. Helton R.R., Liu L., Wommack K.E. Assessment of factors influencing direct enumeration of viruses within estuarine sediments. Appl. Environ. Microbiol., 2006, 72(7): 4767-4774 (doi: 10.1128/AEM.00297-06).

16. Srinivasiah S., Bhavsar J., Thapar K., Liles M., Schoenfeld T., Wom$\mathrm{m}$ a ck K.E. Phages across the biosphere: contrasts of viruses in soil and aquatic environments. Res. Microbiol., 2008, 159(5): 349-357 (doi: 10.1016/j.resmic.2008.04.010).

17. Ro m e ro $-\mathrm{S}$ u a r e $\mathrm{z}$ S., $\mathrm{J}$ ord a $\mathrm{n}$ B., $\mathrm{H}$ e i n e $\mathrm{m}$ a $\mathrm{n} \mathrm{n}$ J.A. Isolation and characterization of bacteriophages infecting Xanthomonas arboricola pv. juglandis, the causal agent of walnut blight disease. World J. Microbiol. Biotechnol., 2012, 28(5): 1917-1927 (doi: $10.1007 / \mathrm{s} 11274-011-0992-\mathrm{z})$.

18. Boyer M., Haurat J., Samain S., Segurens B., Gavory F., González V. Mavingui P., Rohr R., B ally R., Wisniewski-D y é F. Bacteriophage prevalence in the genus Azospirillum and analyses of the first genome sequence of an AzospirilIum brasilense integrative phage. Appl. Environ. Microbiol., 2008, 74(3): 861-874 (doi: 10.1128/AEM.02099-07)

19. Maniat is T., Frisch E.F., S a mbrook J. Molecular cloning: a laboratory manual. Cold Spring Harbor Laboratory, NY, 1982.

20. S mith G.P., S cott J.K. Libraries of peptides and proteins displayed on filamentous phage. Meth. Enzymol., 1993, 217: 228-257.

21. Ko p y lo v E.P. Mikrobiologiya i biotekhnologiya, 2007, 1: 67-73

22. S h e st a k ov S.V. Ekologicheskaya genetika, 2007, 5(2): 12-24.

23. Antonyuk L.P., Ig nat ov V.V. V sbornike: Fundamental'nye i prikladnye issledovaniya saratovskikh uchenykh dlya protsvetaniya Rossii i Saratovskoi gubernii [In: Fundamental and applied research of Saratov scientists for the prosperity of Russia and Saratov Province]. Saratov, 1999: 153-155.

24. Volkog o n V.V. Mikrobiologichnii zhurnal, 2000, 62(2): 51-68. 